\title{
Enes S. Omerović, Nacjonalne manjine u Bosni i Hercegovini (1918- 1941), Institut za Historiju Univerziteta u Sarajevu, Sarajevo 2019, 425 ss.
}

Enes S. Omerović jest przedstawicielem młodej generacji bośniacko-hercegowińskich historyków, który kolejny raz po swojej monografii Političko nasilje u Bosni i Hercegovini (1918-1921) postanowił sięgnąć po temat z okresu międzywojennego. Uczeń Husniji Kamberovića, pod którego okiem powstała niniejsza książka (był promotorem dysertacji doktorskiej stanowiącej podstawę recenzowanej pracy [s. 9]), tym razem skupił się na problemie mniejszości narodowych zamieszkujących Bośnię i Hercegowinę w latach 1918-1941.

Książka została wydana w 2019 roku nakładem wydawnictwa Instytutu Historii Uniwersytetu w Sarajewie (Institut za Historiju Univerziteta u Sarajevu), którego pracownikiem jest autor syntezy. Jej recenzentami są profesor Uniwersytetu w Sarajewie Edin Radusić i pracownik Instytutu Współczesnej Historii Serbii Zoran Janjetović. Praca liczy dziewięć rozdziałów i podsumowanie oraz streszczenie w języku angielskim, jak również aneksy w postaci wybranych informacji ze spisów powszechnych z lat 1910, 1921 i 1931 dotyczących mniejszości narodowych. Ponadto zaopatrzona jest w indeksy: nazwisk i geograficzny. Okładka miękka, papier kredowy.

Cezury czasowe wyznaczone przez autora nie budzą większych wątpliwości. Za początek przyjął on upadek Austro-Węgier i powołanie do życia niezależnych od Wiednia władz, które to wkrótce pozwoliły włączyć Bośnię i Hercegowinę w skład nowo powstałego Królestwa Serbów, Chorwatów i Słoweńców. Koniec zaś to hitlerowski atak na Jugosławię w kwietniu 1941 roku. Mimo tych wyraźnych granic czasowych Omerović często odwołuje się do czasów austro-węgierskich, gdyż to tam właśnie sięga geneza pojawienia się na bośniacko-hercegowińskich ziemiach większości przedstawicieli mniejszości narodowych.

Sam temat recenzowanej syntezy jest niezwykle ciekawy i tylko z pozoru wydaje się łatwy do opracowania. W istocie zajmowanie się mniejszościami w wieloetnicznym kraju, jakim była i pozostaje Bośnia i Hercegowina, nastręcza wielu problemów nie tylko metodologicznych, ale również pojęciowych. $Z$ wagi tego zagadnienia zdał sobie sprawę także autor, który cały pierwszy rozdział poświęcił zdefiniowaniu, czym była owa mniejszość narodowa zarówno w Królestwie SHS/Jugosławii, jak i samej Bośni i Hercegowinie. Autor polemizuje z różnymi koncepcjami, dochodząc wreszcie do wniosku, że wiele zależy od kontekstu historycznego, gdyż rozumienie tego pojęcia było uwarunkowane okresem, w jakim konkretna definicja powstała (s. 33-35). Sam nie decyduje się stworzyć własnej 
definicji, podaje jednak kilka warunków, które najczęściej się powtarzają w dyskusjach na temat mniejszości narodowych (s. 37-38). Na koniec rozdziału możemy poznać kryteria, których Omerović używa, klasyfikując daną grupę jako narodową mniejszość (s. 41-42), autor zauważa jednak, że nie są one kategoryczne i należy podchodzić do nich z naukowym dystansem.

W kolejnym rozdziale autor prezentuje informacje dotyczące demografii wybranych mniejszości zamieszkujących Bośnię i Hercegowinę we wspomnianym okresie. Z pewnością rozdział ten będzie często wykorzystywany do dalszych badan, gdyż Omerović zebrał w jednym miejscu różnego rodzaju informacje, zarówno oficjalne spisy prowadzone przez władze centralne, jak i lokalne statystyki, dzięki czemu możemy dowiedzieć się, jak wyglądała demografia poszczególnych mniejszości narodowych, w tym również polskiej, której autor poświęcił jeden z podrozdziałów (s. 69-72). Stanowiła ona drugą pod względem liczebności mniejszość narodową w tym kraju. Warto w tym miejscu zatrzymać się na moment przy problemie Rusinów, których określa bezpiecznym terminem Rusini/Ukrajinci, ponadto identyfikuje ich wyłącznie z grekokatolikami, mając jednak na uwadze niedoskonałości wynikające z tego faktu (s. 72). Zarówno w wypadku tej mniejszości, jak i innych (np. Czechów, Słowaków, Niemców) autor nie wchodzi zbyt głęboko w temat narodowej tożsamości poszczególnych grup, także genezę ich pojawienia się ogranicza wyłącznie do kilku wzmianek, skupiając się na liczbach i ich analizie.

Trzeci rozdział przynosi kolejne interesujące informacje, tym razem dotyczące struktury ekonomicznej i socjalnej mniejszości narodowych, jak również ich udziału w gospodarce Bośni i Hercegowiny. Ze względu na niedostateczną ilość źródeł, a także ich bardzo różnorodny charakter (s. 90-92) trudno jest określić dokładne liczby, dlatego autor zdecydował się w poszczególnych podrozdziałach zaprezentować wkład mniejszości w życie wiejskie - tym bardziej że większość z przedstawicieli mniejszości parała się właśnie rolnictwem (s. 96) - następnie w miejskie, a także $\mathrm{w}$ działalność związaną z utrzymaniem tożsamości narodowej poszczególnych mniejszości. W rozdziale tym oprócz rozważań ogólnych uwagę zwraca tabela (s. 95), w której autor umieścił informacje o liczbie poszczególnych mniejszości ze względu na miejsce zamieszkania, miasto-wieś. Na przykład o ile mniejszość rosyjska (głównie emigranci porewolucyjni) w prawie $88 \%$ zamieszkiwała miasta, o tyle Polaków w ośrodkach miejskich było tylko niespełna 13\%. Większość zaś stanowili koloniści w wioskach wybudowanych wokół Banja Luki.

Kolejna część zatytułowana „(Nie)uczestniczenie mniejszości narodowych w życiu politycznym Bośni i Hercegowiny" ([Ne]učešće nacjonalnih manjina u političkim životu Bosne i Hercegovine) jest poświęcona aktywności politycznej, a może bardziej jej brakowi, czego nie omieszkał zaznaczyć Omerović. Poza przedstawicielami społeczności żydowskiej, zwłaszcza sefardyjczykami, którzy ze względu na wielopokoleniową obecność na Bałkanach czuli się związani z nim równie mocno jak Muzułmanie, Serbowie czy Chorwaci (s. 132-133), reszta mniejszości narodowych tylko w wyjątkowych sytuacjach miała jakichkolwiek swoich reprezentantów na wyższych stanowiskach w zakresie polityki krajowej. Jedyną polityczną platformą, na jakiej mogli się wykazać, były radykalne, najczęściej 
lewicujące partie (s. 136-137) będące pod policyjną obserwacją, a nieraz nawet likwidowane z powodu swojego radykalizmu. Nieco lepiej sytuacja wyglądała w gminach, co można tłumaczyć tym, że wybór ich władz, a także rola zasadniczo się nie zmieniły od czasów Austro-Węgier (s. 142), poza tym były to najmniejsze jednostki administracyjne, więc ich wybór był mocno uzależniony od woli lokalnej społeczności. Sytuacja zmieniła się dopiero z chwilą przeprowadzenia przez dyktaturę styczniową ( ̌́estojanuarska diktatura) reform. Od tego czasu tylko sporadycznie we władzach gminnych zasiadali przedstawiciele jakichkolwiek mniejszości narodowych (s. 150).

Sprawom szkolnictwa mniejszości narodowych poświęcony jest rozdział piąty. $\mathrm{W}$ nim to Enes S. Omerović szczegółowo omawia kwestie szkolnictwa zarówno tego elementarnego, jak i średniego. W tej części autor wraca do pomysłu z rozdziału drugiego, to znaczy prezentuje szkolnictwo mniejszości narodowych nie w sposób całościowy, jak to było w przypadku rozdziałów trzeciego i czwartego, ale z podziałem na poszczególne grupy narodowe. Co ciekawe, to, czy dana mniejszość narodowa posiadała swoje szkoły z językiem wykładowym przynależnym danej grupie, wcale nie zależało od liczebności danej mniejszości, a jej statutu. Dobrym przykładem są Polacy, którzy mimo że - jak zostało wspomniane - byli drugą co do wielkości mniejszością narodową, nie posiadali swoich szkół (s. 183), podczas gdy takowe mieli zarówno Czesi - relatywnie Czechosłowacy (s. 177), jak i Włosi (s. 179-180). Wszyscy oni, z najliczniejszą niemiecką mniejszością na czele, musieli się jednak borykać z niechęcią jugosłowiańskich polityków, co powodowało, że liczba szkół z językiem obcym jako wykładowym rokrocznie spadała (s. 176). Represje te ominęły Rosjan, którzy jako tradycyjni sojusznicy Serbów mogli liczyć na szczególne względy u władz Jugosławii. Nie inaczej było w Bośni i Hercegowinie, gdzie istniał cały system rosyjskiego szkolnictwa zarówno podstawowego, jak i średniego (s. 185-186).

Dyskryminowani (i w polityce, i w edukacji) przedstawiciele poszczególnych grup narodowych starali się walczyć o swoją pozycję za pomocą zakładanych stowarzyszeń. Temu tematowi jest poświęcony rozdział siódmy. Omerović także tutaj zastosował podział na poszczególne grupy narodowe. Najwięcej miejsca poświęcił stowarzyszeniom żydowskim, nie tylko je wymieniwszy z nazwy, ale również omówiwszy niektóre z nich, jak największe La Benvolencija (s. 194) sięgająca swoimi korzeniami okresu austro-węgierskiego czy towarzystwo muzyczne Lira (s. 196197). Podobny staż miało także czeskie towarzystwo Česka beseda, które nie dość, że przetrwało trudny okres zmian związany z upadkiem monarchii Habsburgów, to jeszcze całkiem nieźle rozwinęło swoją działalność w okresie międzywojnia (s. 210). Sporo Czechów można było również spotkać wśród członków innych towarzystw muzycznych czy sportowych (s. 217), co świadczyło o ich sukcesywnej asymilacji. Jeśli idzie o polskie towarzystwa, niestety niewiele udało się ustalić autorowi ponad to, co było już wiadomo. Na wzmiankę zasługuje jedynie informacja o klubach sportowych, które zakładali mieszkańcy kolonii zamieszkanych przez Polaków (s. 225).

Rozdział siódmy skupia się na wspólnotach religijnych, które działały w Bośni i Hercegowinie i były związane z mniejszościami narodowymi. Pracownik Institutu 
za Historiju najwięcej miejsca poświęcił na przybliżenie sytuacji grekokatolików, gdyż sytuacja Kościoła unickiego była rzeczywiście specyficzna. Hierarchia kościelna ustalona jeszcze w okresie austro-węgierskim była zdaniem autora zmuszona do walki na dwu frontach. $Z$ jednej strony tożsamości narodowej Rusinów zagrażali Polacy będący często ich sąsiadami, z drugiej natomiast Serbowie (s. 264), których prawosławny kler rzeczywiście jeszcze za czasów monarchii habsburskiej prowadził działania na rzecz konwersji unitów na prawosławie. Pewien niedosyt budzić może fragment poświęcony Kościołowi katolickiemu, gdyż autor ledwie wzmiankuje o niezadowoleniu Polaków spowodowanym brakiem polskich księży (s. 253), nie wspomina natomiast zupełnie o konflikcie, jaki istniał między kolonistami a chorwackim klerem, mimo że problem ten, jak wynika z lektury książki, jest mu znany (s. 306).

Ostatnie dwa rozdziały są nieproporcjonalne w stosunku do poprzednich, gdyż łącznie liczą raptem 21 stron (od 293 do 314), w których to autor omówił kwestie dotyczące prasy, jaką wydawały poszczególne mniejszości narodowe, tę część poświęcił również stosunkom między mniejszościami narodowymi a lokalną społecznością. To właśnie ten ostatni rozdział budzi w mojej opinii najwięcej wątpliwości. Omerović sporo miejsca poświęcił na przybliżenie sytuacji, która miała miejsce krótko po tym, jak upadły Austro-Węgry, i powtórzył poniekąd swoje wnioski z poprzednio wydanej monografii, której tytuł wzmiankowałem na początku. Okres ten jest specyficzny nie tylko w Bośni i Hercegowinie, ale właściwie wszędzie na pograniczu, gdzie mieszały się z sobą różne narodowości. Także w Polsce zdarzały się akty agresji w stosunku do Niemców, którzy mieli nieszczęście znaleźć się po polskiej stronie granicy, co miało miejsce na Śląsku czy na Pomorzu ${ }^{1}$. Dlatego nie sądzę, by opieranie swoich wniosków o stosunkach między miejscowymi a mniejszościami w okresie międzywojennym na podstawie pierwszych powojennych miesięcy było słusznym kierunkiem. Wszak dopiero w kilka lat po upadku Austro-Węgier pojawiać się zaczęła refleksja na temat tego, co się rzeczywiście wydarzyło i czy faktycznie okres rządów Habsburgów był w porównaniu do dyktatur rządzących Europą Środkowo-Wschodnią taki zły ${ }^{2}$, co miało swoje przełożenie choćby na stosunek wobec Niemców czy Węgrów.

Co prawda Omerović sięga po kilka dokumentów z lat 30., jednak nie jest tego wiele, a poza tym przytoczone źródła, jak na przykład relacja Marii Dąbrowskiej z jej pobytu w Jugosławii, jest, mówiąc krótko, za mało wiarygodna, by wysnuwać na jej podstawie jakieś ostateczne wnioski. Wydaje się, że autor trochę pospieszył się przy tworzeniu tej części książki, gdyż - zwłaszcza w kontekście poprzednich rozdziałów - ten wygląda, jak gdyby był nie do końca dopracowany, o czym świadczy zarówno baza źródłowa, jak i jego objętość - dziewięć stron! Z pewnością potencjał był większy i można było napisać go dużo ciekawiej, opierając się na zdecydowanie obszerniejszym materiale źródłowym.

${ }^{1}$ Por. M. Stażewski, Eksodus, migracja ludności niemieckiej z Pomorza do Rzeszy po I wojnie światowej, Gdańsk 1998.

2 A. Kożuchow sk i, Pośmiertne dzieje Austro-Wegier. Obraz monarchii habsburskiej w piśmiennictwie międzywojennym, Warszawa 2009, s. 139-143. 
Całość pracy wieńczą dość obszerne wnioski autora, co do których nie ma żadnych zastrzeżeń, gdyż wynikają one z lektury poszczególnych części pracy. Zarówno w Bośni i Hercegowinie, jak i w całej Jugosławii mniejszości były traktowane jak sam autor twierdzi - jak kamień u nogi (kamen oko vrata) (s. 324), chociaż, jak zauważa, ich sytuacja w porównaniu z resztą kraju była relatywnie lepsza, zarówno jeśli idzie o możliwości rozwijania swoich stowarzyszeń, jak i w podejściu do nich lokalnej społeczności.

Po raz kolejny natomiast chciałbym pochwalić autora za dobór odpowiedniego materiału statystycznego, który zaprezentował w postaci aneksów. Dokumenty te zdecydowanie podnoszą atrakcyjność książki.

Dysertacja Enesa S. Omerovića ze względu na swoją tematykę stanie się punktem odniesienia dla wielu kolejnych badaczy, którzy będą podejmować temat mniejszości narodowych zarówno w Jugosławii, jak i w Bośni i Hercegowinie w okresie międzywojennym. Synteza spełnia swoją podstawową funkcję - jest to kompendium wiedzy, które przez większość rozdziałów (poza ostatnimi dwoma) prowadzi nas przez świat mniejszości narodowych, odpowiadając potrzebom osób, które chciałyby zgłębić temat. Kilka słów należy poświęcić materiałowi źródłowemu oraz literaturze. Co do archiwaliów trudno jest mieć większe zastrzeżenia, gdyż wykorzystane materiały z archiwów w Bośni i Hercegowinie (Sarajewo i Banja Luka), jak i w Serbii (Belgrad) są w pełni satysfakcjonujące. Oczywiście zawsze można było jeszcze posłużyć się materiałami z Tuzli czy Mostaru, nie sądzę jednak, by kwerenda tam przeprowadzona znacząco wzbogaciła rozważania autora. Także drukowane materiały źródłowe nie budzą żadnych wątpliwości.

O ile nie można mieć więc zastrzeżeń do materiałów źródłowych - ani archiwalnych, ani drukowanych - w porównaniu z nimi dość ubogo prezentuje się literatura. Autor jest doskonale zorientowany w literaturze południowosłowiańskiej, ale książka dotycząca mniejszości narodowych wymaga tego, by użyć w niej prac dotyczących poszczególnych grup narodowych, które powstały za granicą. Tych natomiast jest niewiele, ponadto sprawiają wrażenie, jakby ich dobór był przypadkowy. Z pewnością wykorzystanie czeskiej, polskiej czy niemieckiej literatury przedmiotu zdecydowanie podniosłoby poziom recenzowanej publikacji, być może wpłynęłoby również na niektóre wnioski autora.

Książka autorstwa Enesa S. Omerovića stanowi doskonałą pozycję dla osób, które szukają ogólnych informacji o mniejszościach narodowych w Bośni i Hercegowinie. Można ją traktować jako swoiste kompendium wiedzy na wybrany temat, gdyż autor dotyka bardzo wielu wątków, co może być zarówno zaletą, jak i w pewien sposób wadą, gdyż pewne tematy traktuje dość ogólnikowo. Z pewnością na pochwałę zasługuje bogata baza źródłowa stanowiąca doskonały punkt wyjścia do dalszych badań. Język, jakiego używa autor, jest prosty, konkluzje zaś logiczne, dzięki czemu książkę czyta się szybko i przyjemnie. Z pewnością jest to jedna $\mathrm{z}$ ważniejszych książek w bośniacko-hercegowińskiej historiografii ostatnich lat, gdyż wypełnia istniejącą lukę. Temat mniejszości narodowych w tym kraju w okresie międzywojennym dotychczas był traktowany w sposób przyczynkowy, Omerović natomiast pokusił się o sprawnie napisaną syntezę, którą można polecić 
każdemu, zarówno naukowcowi zaznajomionemu z tematem, jak i laikowi chcącemu dowiedzieć się czegoś o wybranych mniejszościach narodowych w Bośni i Hercegowinie w okresie międzywojennym.

Tomasz Jacek Lis (D) http://orcid.org/0000-0003-0188-5755

Wyższa Szkoła Kultury Społecznej i Medialnej Adres do korespondencji: tomlis88@gmail.com 